NBER WORKING PAPER SERIES

LAYOFFS AND LEMONS

Robert Gibbons

Lawrence Katz

Working Paper No. 2968

http://www, nber.org/papers/w 2968

NATIONAL BUREAU OF ECONOMIC RESEARCH

1050 Massachusetts Avenue

Cambridge, MA 02138

May 1989

We are grateful for helpful comments from Orley Ashenfelter, Laurence Ball, David Card, James Dow, Henry Farber, Alan Krueger, Bruce Meyer, Kevin J. Murphy, Kevin M. Murphy, Barry Nalebuff, Julio Rotemberg, Garth Saloner, Andrei Shleifer, Lawrence Sumers, Robert Topel, and Robert Vishny, as well as from participants in an MIT Labor Lunch and seminars at Carnegie-Mellon, McMaster, the NBER (1988 Summer Institute), Princeton, and Rochester. We thank Alan Krueger and Doug Kruse for providing us with extracts from the Displaced Workers Supplements. Financial support from the following sources also is gratefully acknowledged: National Science Foundation grant SES 8809200 (both authors); the Industrial Relations Section at Princeton University (Gibbons); and an NBER Olin Fellowship in Economics (Katz). This paper is part of NBER's research program in Labor Studies. Any opinions expressed are those of the authors not those of the National Bureau of Economic Research. 
NBER Working Paper \#2968

May 1989

\title{
LAYOFFS AND LEMONS
}

\begin{abstract}
In this paper we provide theoretical and empirical analyses of an asymmetric-information model of layoffs in which the current employer is better informed about its workers' abilities than prospective employers are. The key feature of the model is that when firms have discretion with respect to whom to lay off, the market infers that laid-off workers are of low ability. Since no such negative inference should be attached to workers displaced in a plant closing, our model predicts that the postdisplacement wages of otherwise observationally equivalent workers will be higher for those displaced by plant closings than for those displaced by layoffs. An extension of our model predicts that the average postdisplacement unemployment spell of otherwise observationally equivalent workers will be shorter for those displaced by plant closings than for those displaced by layoffs.

In our empirical work, we use data from the Displaced Workers Supplements in the January 1984 and 1986 Current Population Surveys. We find that the evidence (with respect to both re-employment wages and postdisplacement unemployment duration) is consistent with the idea that laidoff workers are viewed less favorably by the market than are those losing jobs in plant closings. Our findings are much stronger for workers laidoff from jobs where employers have discretion over whom to lay off.

Robert Gibbons

Department of Economics MIT

Cambridge, MA 02139

Lawrence F. Katz

Department of Economics

Harvard University

Cambridge, MA 02138
\end{abstract}




\section{Introduction}

Since the seminal work of Akerlof (1976) and Spence (1973), labor economists have understood that asymmetric information about workers' productive abilities can affect labor-market outcomes. A number of recent theoretical papers have elaborated on this theme, and also have shifted attention from a worker's private information (vis a vis prospective employers) about his or her productive ability to an employer's private information (vis a vis the market) about an employee's ability. Waldman (1984), Milgrom and Oster (1987), and Ricart i Costa (1988), for instance, describe inefficient job assignments that result when an employer has private information concerning employees' abilities, and Greenwald (1986), Lazear (1986), and Riordan and Staiger (1987) describe analogous consequences for wages and mobility in the presence of such asymmetric information.

It seems plausible that a worker's current employer may be better informed about the worker's ability than prospective employers are, but the predictions generated by the existing theoretical models based on this assumption mainly concern variables that are not included in standard micro data sets (such as promotions within the firm or wage offers from prospective employers). As a result, there have been (to our knowledge) no empirical tests of these predictions. It therefore seems prudent to develop an asymmetric-information model that generates new testable predictions and to check that these predictions are not wildly at odds with the facts.

In this paper we provide theoretical and empirical analyses of an asymetric-information model of layoffs in which the current employer is better informed about its workers' abilities than prospective employers 
are. Our theoretical model offers new answers to such time-honored questions as why layoffs occur and how firms determine which workers to lay off, ${ }^{1}$ and our empirical work offers the first quantitative evidence consistent with the burgeoning collection of asymmetric-information models described above.

The main idea behind the paper is simple: a firm's desire to retain a worker signals to the market that the worker is of high ability, so the market bids up the wage of retained workers; as a result, the firm finds it unprofitable to retain low-ability workers and hence lays them off. ${ }^{2}$ The market then infers that laid-off workers are of low ability, and so offers them low wages in their next jobs. Workers displaced by plant closings, in contrast, suffer from no such adverse inference and so receive (relatively) higher re-employment wages from the market. Our model thus predicts that the post-displacement wages of (otherwise observationally equivalent) workers will differ according to the cause of displacement.

In our empirical work, we use data from the Displaced Workers Supplements in the January 1984 and 1986 Current Population Surveys. We find that the evidence is consistent with the hypothesis that (permanently) laid-off workers are viewed less favorably by the market than are those losing jobs in plant closings: For our sample (of males) as a whole, workers displaced by a layoff suffer a 4 percent greater wage loss than do

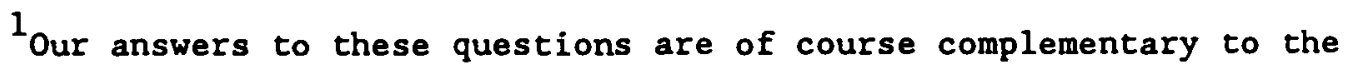
conventional wisdom that layoffs are caused by shocks and determined by seniority.

${ }^{2}$ One might ask why low-ability workers cannot be retained at a low wage. As will become clear below, the answer is that if the firm could retain low-ability workers at a low wage then it would also retain highability workers at this low wage, thereby destroying the market's willingness to allow any workers to be retained at the low wage. 
workers displaced by a plant closing. Furthermore, among white-collar workers, the extra wage loss from a layoff is 5.5 percent, and for whitecollar workers with at least two years of pre-displacement job tenure it is 8.7 percent. As we explain below, these stronger effects for the whitecollar and the high-tenure, white-collar sub-samples are also implied by our model, because the information content of a layoff is greater where employers have both better information about workers' abilities and the opportunity to act on this information.

In addition to predicting that post-displacement wages should differ by cause of displacement, the lemons model we develop also predicts that there should be no post-displacement unemployment. It is simple to extend the model, however, so that the spirit of the prediction about wages carries over to a prediction about unemployment durations: the average post-displacement unemployment duration should be longer for workers displaced by layoffs than for those displaced by plant closings. We find that the evidence also is consistent with this prediction: workers laid-off (and not recalled) have approximately 25 percent longer post-displacement unemployment spells than do those displaced in plant closings. As we describe below, only part of this estimate should be attributed to a lemons effect, but we also report several further pieces of evidence that together suggest an important role for our lemons model in accounting for the observed variation in post-displacement unemployment duration by cause of displacement and by occupation.

In sum, we find that the evidence with respect to both re-employment wages and post-displacement unemployment duration is consistent with the idea that laid-off workers are viewed less favorably by the market than are 
those losing jobs in plant closings. In interpreting these empirical results, it is worth noting that they do not control for a potentially important effect in the opposite direction: if a plant is large compared to its local labor market, then the increase in the local unemployment rate following a plant closing seems likely both to depress the re-employment wages and to extend the typical unemployment duration of displaced workers. We view our empirical results as satisfying a necessary (but not sufficient) condition for confidence in models based on asymetric information about workers' abilities: had our estimates rejected our model, it would have cast serious doubt on the entire family of models based on the information asymmetry we analyze. Alternatively, our empirical results can be interpreted as support for various symmetric-information models, as we discuss in detail below.

The body of the paper is organized as follows. Section 2 presents the theoretical model. Sections 3 and 4 present the empirical results on wages and unemployment duration, respectively. Section 5 summarizes and interprets our findings.

\section{The Theoretical Model}

In the signaling equilibrium described below, a firm lays off its least productive workers. Prospective employers then infer that these workers are of low productivity and so offer them a low wage. Because no such inference occurs after a plant closing, the re-employment wage of workers who lose their jobs because of a plant closing is higher than that of workers who lose their jobs because of a layoff. Our model of layoffs 
is closely related to Waldman's (1984) model of job assignment: in

Waldman's model, the firm assigns low-ability workers to a menial job (1.e., a job for which output is independent of ability); here, the firm lays off these workers.

The model has two periods. The major elements of the model are (1) the production technology, (2) the information structure, (3) the commitment and contracting possibilities, and (4) the timing of events between periods one and two. We discuss each of these elements in turn.

(1) The production technology: The first-period output of a worker of (time-invariant) productive ability $\eta$ is $y_{1}(\eta)=\eta$. The second-period output of a worker of ability $\eta$ is $y_{2}(\eta)-(1+s) \eta$ (where $s>0$ ) if the worker remains with the first-period employer, but is $y_{2}(\eta)-\eta$ if the worker changes employers. The parameter $s$ therefore represents the acquisition of firm-specific human capital. ${ }^{3}$

(2) The information structure: At the beginning of the first period, information is symmetric: all firms and all workers share the belief that workers' productive abilities are independently and identically distributed according to the (atomless) distribution $F(\eta)$ on $(0, \eta)$, with (strictly positive) density $f(\eta) .4$ At the end of the first period, the worker's current employer observes the worker's first-period output and so perfectly infers the worker's ability. Prospective employers, however, do not observe output and so do not (yet) update their beliefs about the worker's

${ }^{3}$ All of our qualitative conclusions also emerge from the alternative model in which $y_{2}(\eta)=\eta+s$, provided $s$ is not extremely large. The firm-specific human capital (s) in this alternative model can also be interpreted as a mobility cost.

${ }^{4}$ Note that we assume that the lowest possible productive ability is zero. This avoids unenlightening complications in what follows. 
ability. Finally, to keep things simple, we make assumptions below (on the kinds of wage and employment contracts that are feasible) to guarantee that it is immaterial whether or not the worker observes first-period output.

In the interest of clarity, we impose a (rather weak) regularity condition on the distribution of productive ability: $f(\eta)$ must be logconcave (i.e., ln $f(\eta)$ must be concave in $\eta$ ), which implies that $\mathrm{d}(\mathrm{E}(\eta \mid \eta \geq \mathrm{x})\} / \mathrm{dx} \leq 1$ for every $x .^{5}$ Many familiar distributions--including the uniform, Normal, exponential, and beta distributions---satisfy this condition. Furthermore, the truncation of a log-concave distribution is log-concave.

(3) Contracting Possibilities: We assume that neither contingent nor long-term contracts are possible. Thus, for example, the first-period wage cannot be contingent on the worker's first-period output. Similarly, the firm cannot commit to paying a second-period wage that is contingent on first-period output (but in equilibrium, once the second period arrives, the firm does choose to pay a wage that depends on ability, as described below). In effect, each period's wages are paid in advance: $w_{1}$ is paid at the beginning of the first period and $w_{2}$ is both determined and paid at the beginning of the second.

The assumption that contracts contingent on output cannot be enforced fits naturally with our assumption that output is not observable by

${ }^{5}$ See Caplin and Nalebuff (1989) and Heckman and Honore (1987) for proofs of this result. We assume log-concavity for two reasons: First, it greatly simplifies the proof of our existence and uniqueness results in Proposition 1 (but it is worth noting that much weaker assumptions would also be sufficient; see Caplin and Nalebuff). Second, while the predictions examined in our empirical work require only Proposition 1, we find that one's intuitive grasp of the model is enhanced by the comparative-static results we present in the text, the proofs of which rely on log-concavity. 
prospective employers (and so plausibly also is unobservable to a court). The assumption that long-term contracts cannot be enforced seems natural because of the possibility that firm-specific productivity shocks may occur: if a bad enough shock occurs at the beginning of period two, the current employer will go bankrupt rather than live up to the contract. Given our empirical focus on permanently displaced workers, such productivity shocks are a realistic component of the model. For simplicity, we do not include shocks in the model analyzed here; in Appendix 1 we show that the empirical predictions are identical in the analogous model that does include shocks.

One consequence of these two assumptions on contracting possibilities is that it is immaterial whether workers are risk-neutral or risk-averse. Another consequence is that, just as it is impossible to enforce contingent or long-term contracts concerning wages, so too is it impossible to enforce contingent or long-term contracts concerning layoffs. Thus, for example, it is impossible to enforce a contract that guarantees that the employer will not lay off any workers and will pay them all some fixed second-period wage $w_{2}$

(4) Timing: The crux of the model is the sequence of events between the two periods. After observing a given worker's first-period output, the current employer decides whether to lay off or retain the worker. If the worker is laid off then the current employer has no further contact with the worker; in particular, there is no possibility of recall. If the current employer wishes to retain the worker, however, then the following wage-setting game ensues. First, the current employer offers the worker a second-period wage. Second, prospective employers observe that the worker 
was not laid off by the first-period employer, but do not observe the current employer's second-period wage offer. Third, prospective employers simultaneously offer the worker second-period wages. And fourth, the worker chooses the highest wage offered (and chooses the offer of the current employer in case of a tie).

We have simplified the analysis considerably by restricting the space of signals available to the informed party: prospective employers observe the current employer's decision to lay off or retain a worker, but do not observe the current employer's wage offer to retained workers. Fortunately, our simple model yields precisely the same empirical predictions as do many alternative models of the timing and extent of wage offers by the firm and counteroffers by prospective employers; in particular, it is straightforward to show that identical empirical predictions arise if the current employer's wage offer to the worker is assumed to be observed by the market. 6

The analysis of the wage-setting game is straightforward. In principle, the current employer's (unobservable) second-period wage offer to a particular worker could vary with the employer's information about the worker's ability, but in (a pure-strategy) equilibrium it does not: in equilibrium, the current employer offers each worker whom it wishes to retain exactly the second-period wage that prospective employers will later offer these workers.

'More specifically, if the current employer's wage offer is observed by the market, then in a pure-strategy equilibrium the retained workers are those above the ability cutoff we identify and are paid the wage we identify. In some equilibria, the wages paid to laid-off workers vary, possibly with their abilities, but the average of these wages is always the wage we identify, and it is this average that is measured in our (crosssectional) empirical work. 
Formally, suppose prospective employers conjecture that workers of ability $\eta \geq \eta *$ are retained while workers of ability $\eta<\eta *$ are laid off. ${ }^{7}$ Competition among these employers then leads to the second-period wage offers

$$
w_{2}(R)=E(\eta \mid \eta \geq \eta *) \text { and }
$$

$$
w_{2}(L)=E(\eta \mid \eta<\eta *)
$$

for retained and laid-off workers, respectively.

To retain a worker, the current employer must (at least) match the outside wage offer given in (1). Therefore, the current employer's best response is to retain workers of ability $\eta$ satisfying

$$
y_{2}(\eta)-w_{2}(R) \geq 0, \quad \text { or }
$$

$$
\eta \geq E(\eta \mid \eta \geq \eta *) /(1+s)
$$

and to pay them $w_{2}(R)$. Note well that it is not a best response for the current employer to pay different wages to different retained workers, even if the differences in wages thereby correspond to differences in ability.

7 Note that this formulation assumes that the market's conjecture about the abilities of laid-off workers does not vary with the total number of workers laid off by a particular firm (or with the total number of workers retained by the firm). This assumption is consistent with the view that the market observes only the aggregate pool of laid-off workers rather than firm-specific information. Other equilibria exist if the market's conjecture is allowed to vary with firm-specific information, but all of these equilibria share the prediction that laid-off workers are from a lower tail of the ability distribution. 
In equilibrium, the prospective employers' conjecture, $\eta *$, must be correct, so the righthand side of (4) must equal $\eta^{*}$, or

$$
\eta *(1+s)-E(\eta \mid \eta \geq \eta *)
$$

It is simple to show that (5) has a unique solution: At $\eta *=0$ the righthand side of (5) exceeds the left. At $\eta *-\eta$ the lefthand side exceeds the right. And the derivative of the lefthand side with respect to $\eta *$ is $(1+s)$, which exceeds the derivative of the righthand side, because the latter is bounded above by 1 because $f(\eta)$ is log-concave. This proves 8

Proposition 1: There exists a unique pure-strategy equilibrium: workers of ability $\eta<\eta^{*}$ are laid off by their first-period employers and then receive the second-period wage $w_{2}(L)$ from the market.

Note that Proposition 1 guarantees that the equilibrium just described is unique. In particular, given our assumptions, it is not an equilibrium for the firm to retain all of its workers for the second period, whatever their ability levels, even though doing so would make efficient use of the workers' firm-specific human capital. To see why this is so, recall that neither contingent nor long-term contracts are feasible: the firm's wage

${ }^{8}$ The argument above begins by assuming that the market conjectures that an upper tail of the ability distribution is retained and that the complementary lower tail of the distribution is laid off. It is simple to show, however, that for any conjecture by prospective employers about the abilities of the retained workers, the current employer's best response is still to retain an upper tail of the ability distribution and to pay all retained workers the wage that will match the market's subsequent offer. Thus, since in equilibrium the market's conjecture must be correct, the conjecture must be of the form assumed in the text. 
offers and retention decisions between the first and second periods must be (privately) optimal given the firm's information at that point. Thus, no worker will be retained at a wage exceeding his or her (firm-specific) productivity. But we argued above that there can be only one wage paid to retained workers and that it must have the form given in (1) for some value of $\eta^{*}$. Therefore, the wage paid to retained workers must exceed $E(\eta)$, so low-ability workers...-including (but not only) those with ability $(1+s) \eta<$ $E(\eta)$-.-will not be retained.

The unique equilibrium defined by (5) is especially tractable in the case in which $\eta$ is uniformly distributed on $[0,1]$, because the conditional expectations in (1) and (2) are linear in $\eta^{*}$. Simple calculations show that for this case (5) becomes

$$
\eta *=1 /(1+2 s) \text {. }
$$

Note that $\eta^{*}$ approaches zero as $s$ approaches infinity and that $\eta^{*}$ approaches one as $s$ approaches zero: only when firm-specific human capital becomes infinitely important do inefficient layoffs disappear from the equilibrium, while if there is no firm-specific human capital then the entire workforce is laid off. ${ }^{9}$ (It is straightforward to show that these results are not specific to the uniform distribution, but rather hold for all log-concave distributions: implicitly differentiate (5) and observe that $d\left(E\left(\eta \mid \eta \geq \eta^{*}\right)\right\} / d \eta^{*} \leq 1$ because $f(\eta)$ is log-concave.) The intuition

${ }^{9}$ Our assumption that the lowest possible value of $\eta$ is zero makes a (small) difference here. If the lowest value of $\eta$ were $x>0$, then a large but finite value of $s$ would eliminate layoffs: if $x(1+s)>E(\eta)$ then the firm finds it profitable to retain the entire workforce. 
behind these results follows from the fact that---as in any lemons problem, from Akerlof (1970) on---the current employer considers the productivity (in that firm) of the marginal retained worker, while prospective employers consider the productivity (in their firms) of the average retained worker. Some level of firm-specific human capital $(s>0)$ is necessary for these two productivities to be equal.

It remains only to compute the re-employment wage of workers who lose their jobs because of a plant closing. We assume that no inference about the workers' abilities is warranted following a plant closing, so that competition among prospective employers yields the wage

$$
w_{2}(P C)=E(\eta)
$$

Comparing (7) and (2) shows that $w_{2}(P C)>w_{2}(L)$; this inequality is the main prediction of our model. In our empirical work, however, we consider wage changes as well as re-employment wages. In our model, competition among employers and the symmetric information before period one yield a single first-period wage $w_{1}$ for all workers, independent of ability. Therefore, the wage changes experienced by displaced workers satisfy $w_{2}(P C)-w_{1}>w_{2}(L)-w_{1}$.

\section{Empirical Analysis of the Wages of Displaced Workers}

In this section, we provide evidence on the wages of male displaced 
workers, ${ }^{10}$ using data from the January 1984 and January 1986 Displaced Workers Supplements (DWS) to the Current Population Survey. ${ }^{11}$ We examine how the change in wages, the pre-displacement wage, and the postdisplacement wage vary with the cause of displacement and with predisplacement occupation.

\section{A. Data Description}

We examine a pooled sample of male workers between the ages of 20 and 61 who were permanently displaced from a private-sector, full-time, nonagricultural job because of a plant closing, slack work, or a position or shift that was eliminated; we classify as layoffs those displaced because of slack work or a position or shift that was eliminated. Workers displaced from construction jobs were also eliminated from the sample since it is difficult to formulate an appropriate definition of permanent displacement from a construction job. For most of this section, the sample is restricted to those individuals who were re-employed in wage-and-salary

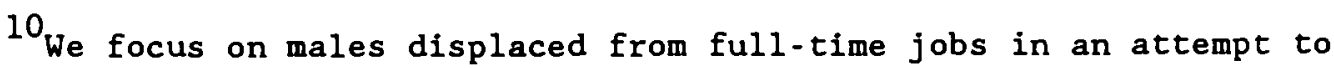
identify a sample of workers with strong attachments to the labor market. This allows us to focus on the impact of the lemons effect on wages alone rather than also jointly modeling the impact on labor-force participation.

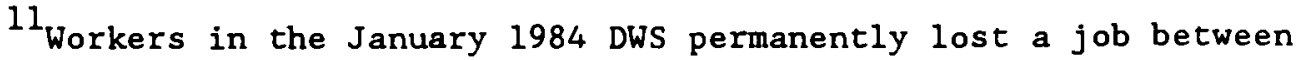
January 1979 and January 1984. Workers in the January 1986 DWS permanently lost a job between January 1981 and January 1986. Individuals enter the DWS if they lost a job in the five years prior to the survey because of plant closing, an employer going out of business, or a layoff from which he or she was not recalled. Interviewers for the DWS were instructed that if an individual was fired from a job for cause then the individual should not be included in the DWS. If a worker lost more than one job in the five years prior to the survey, the survey questions refer to the lost job he or she had held the longest. See U.S. Department of Commerce (1986) for further details on the design and implementation of the DWS surveys. 
employment $^{12}$ at the survey date and who had re-employment earnings of at least $\$ 40$ a week; at the end of the section, we address the potential sample-selection bias arising from the fact that we exclude from the sample workers not re-employed at the survey date.

Basic descriptive statistics for our sample of displaced workers are presented in Table 1. The sample is approximately evenly split between those displaced through plant closings and those displaced by layoffs. The vast majority (79 percent) of those whom we classify as displaced by layoffs were displaced because of slack work. The major measured difference between workers displaced by plant closings and those displaced by layoffs is that, on average, the former had been on their predisplacement jobs substantially longer (2.2 more years). This suggests that seniority rules may be important in layoff decisions. Other measured differences between workers displaced by plant closings and those displaced by layoffs are: on average, the former have shorter spells of joblessness following displacement, are more likely to have found new jobs without an intervening spell of unemployment, and are more likely to have received advance notification of job loss.

The earnings loss for the typical displaced worker in the sample is substantial. The mean change in the $\log$ of real weekly earnings is -0.16 for the whole sample, and does not differ much between those displaced by plant closings and those displaced by layoffs. Much evidence indicates, however, that the earnings losses of displaced workers rise substantially with pre-displacement tenure (e.g., Kletzer, 1988; Podgursky and Swaim,

${ }^{12}$ Unfortunately, the CPS does not provide current earnings information for those workers who entered self-employment. 
Table 1: Descriptive Statistics for Displaced Workers Data Set

January 1984 and 1986 CPS Displaced Workers Surveys

Males Re-employed At Survey Date in Wage and Salary Employment

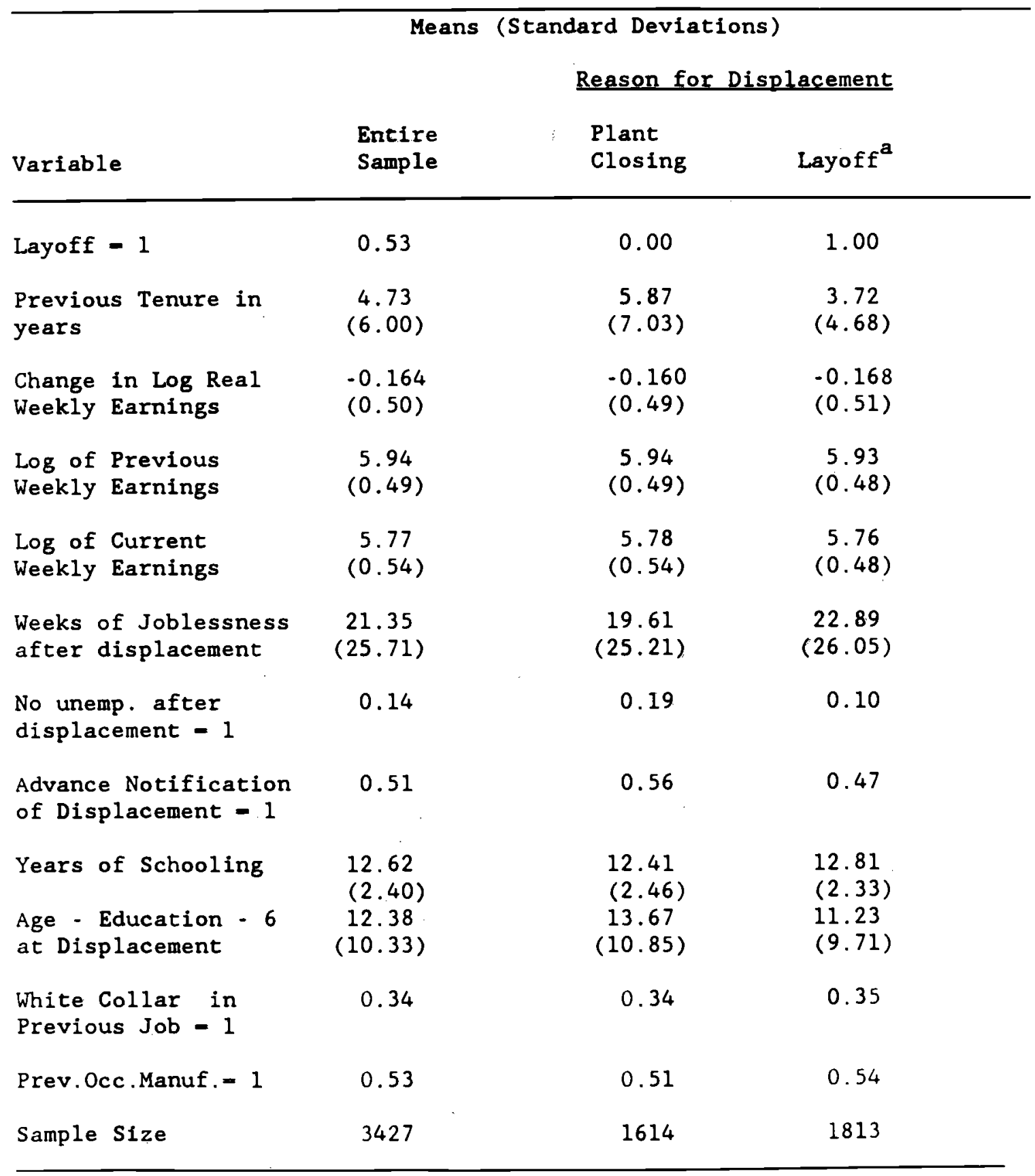

${ }^{a}$ Reason for displacement was slack work or shift or position eliminated.

All weekly earnings figures are deflated by the GNP deflator. 
1987; and Tope1, 1988). Thus, the fact that the earnings losses of workers displaced by layoffs and by plant closings are similar despite the higher average pre-displacement tenure of those displaced by plant closings suggests that a lemons effect may be operating.

The information content of a layoff depends on whether the employer has some discretion with respect to whom to lay off. In the presence of a layoff-by-seniority rule, for example, there may be little or no information concerning a worker's ability revealed by the fact that the worker was laid off. Most jobs covered by collective-bargaining agreements are governed by layoff-by-seniority rules, but many nonunion jobs are not governed by such rules. ${ }^{13}$ This suggests examining whether the gap between the wage losses from layoffs versus those from plant closings is larger in sub-samples where employers are likely to have more discretion with respect to whom to lay off. ${ }^{14}$

Because many fewer white- than blue-collar jobs are covered by collective-bargaining agreements, ${ }^{15}$ we presume that the degree of

${ }^{13}$ Abraham and Medoff (1984), for instance, find that (1) 92 percent of union firms have written rules to deal with permanent layoffs while only 24 percent of nonunion firms have such written layoff policies, and that (2) 58 percent of nonunion firms have a practice of sometimes laying off a more senior worker if a junior worker is belleved to be worth more on net, as compared to 17 percent of union employers.

14 Unfortunately, the Displaced Workers Supplements do not provide information on whether a worker's pre-displacement job was covered by a collective-bargaining agreement.

15 We used all twelve outgoing rotation groups from the 1983 Current Population Survey to tabulate unionization rates by occupation for a sample of workers comparable to our DWS sample. We included in our sample 20 to 61 year-old, male, full-time, private-sector employees not working in agriculture or construction. Workers were classified as unionized if they were union members and/or working in employment covered by a collectivebargaining agreement. We find that 10.4 percent of white-collar workers were unionized, compared to 38.5 percent of blue-collar workers; see Table 
discretion over whom to lay off is likely to be higher in white- than in blue-collar jobs: Differences in the characteristics and displacement experiences of displaced workers by cause of displacement are presented separately for white- and blue-collar workers in Table 2. The difference in average pre-displacement tenure between workers displaced by plant closings and those displaced by layoffs is significantly smaller for whitecollar workers than it is for blue-collar workers ( 1.3 versus 2.6 years). This suggests that strict layoff-by-seniority rules are less important and employer discretion is more important for layoff decisions concerning white-collar workers than for those involving blue-collar workers. ${ }^{16}$ The significantly lower fraction of white- than of blue-collar layoff victims who received advance notification of displacement $(0.41$ versus 0.51$)$ also suggests that white-collar layoffs are less likely to be governed by collective-bargaining agreements, which often include formal prenotification requirements and formally limit employer choice with respect to whom to layoff.

Table 2 also reveals that the pattern of (raw) earnings losses for white-collar workers fits the predictions of our model: pre-displacement

3 for the mapping from one-digit occupations to these white-collar and blue-collar aggregates.

${ }^{16}$ We also computed the difference in average pre-displacement tenure between workers displaced by plant closings and those displaced by layoffs for one-digit pre-displacement occupations rather than for our white- and blue-collar occupational aggregates. Among white-collar workers, the average difference in tenure (in years) is: managers and administrators 1.4; professional and technical workers $=1.6$; clerical workers $=1.2$; and sales workers - 1.2. Among blue-collar workers, the average (in years) is: craft and kindred workers $=2.7$; operatives (except in transportation) = 2.8 ; transport operatives $=2.2$; laborers $=3.1$; and service workers $=1.4$. Thus, with the exception of service workers, the white-versus and bluecollar division of the sample closely matches the division of the sample in terms of this average difference in pre-displacement tenure. 
Table 2: Descriptive Statistics By Broad Occupation

January 1984 and 1986 CPS Displaced Workers Surveys Males Re-employed At Survey Date in Wage and Salary Employment

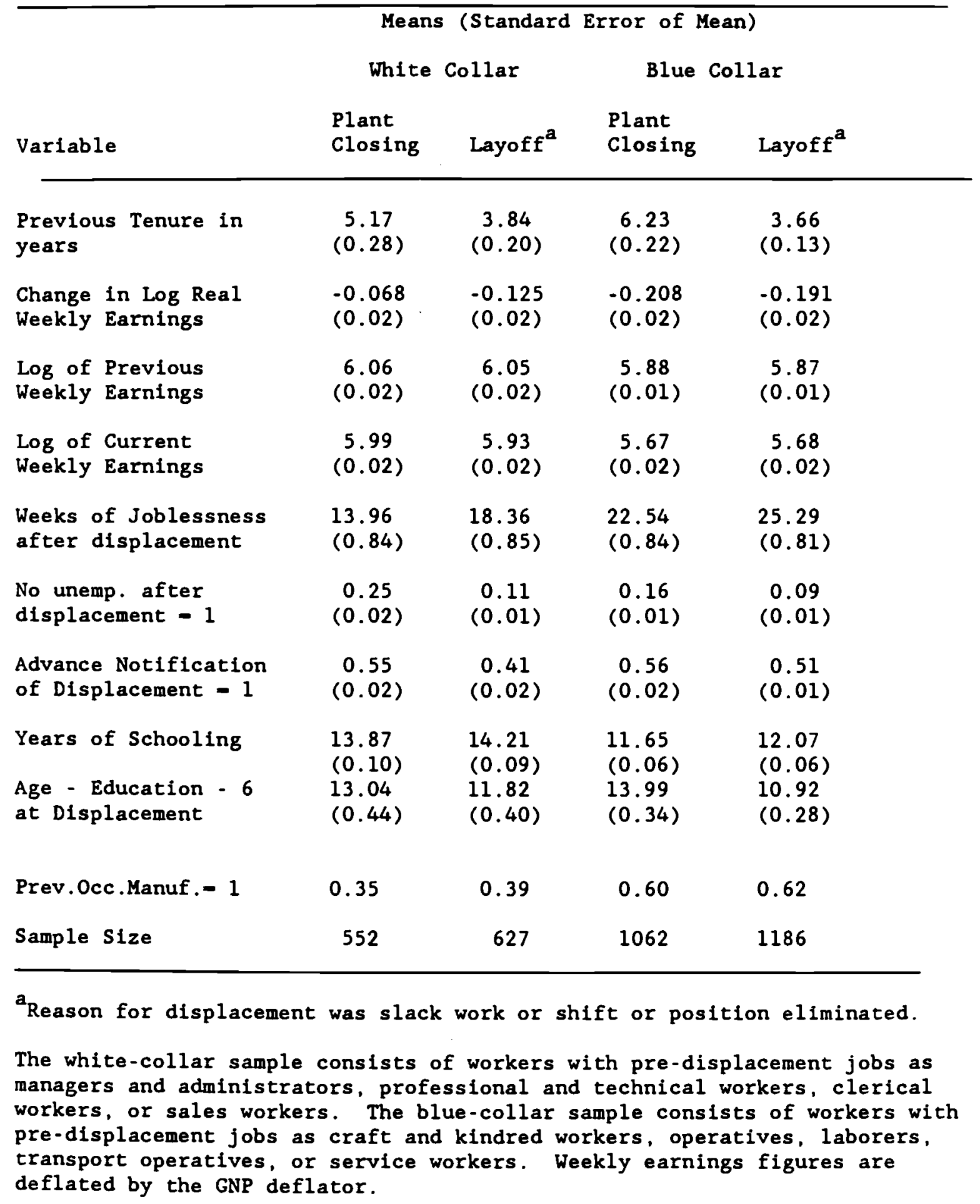


earnings do not differ much by cause of displacement, while post-

displacement earnings are significantly lower (by 6 percent) for those displaced by layoffs. Furthermore, for blue-collar workers the analogous difference in post-displacement earnings is not significantly different from zero, again as predicted by the model.

\section{B. Earnings Equations}

The raw earnings changes suggest that some stigma is attached to being laid off when employers are likely to be able to pick whom to lay off, but that no stigma is attached to being laid off from jobs where formal rules are more likely to govern layoff decisions. To continue to assess the empirical support for the predictions of our model, we present estimates in Table 3 of the coefficient on a layoff dummy in regressions of (i) the change in wages, (ii) pre-displacement earnings, and (iii) post-

displacement earnings on a standard set of worker characteristics, year-ofdisplacement dummies, region dummies, a dummy variable for advance notification of displacement, and one-digit pre-displacement occupation and industry dummies. 17

The estimates for the whole sample presented in Table 3 provide some support for the model's basic prediction: the estimate in column (1) reveals that workers displaced through layoffs experience approximately 4 percent larger wage reductions than do workers with the same measured pre-

17 The wage-change and post-displacement earnings equations also include years since displacement. We have also estimated the wage-change and post-displacement earnings equations replacing the years-sincedisplacement variable with a full set of interactions between the year-ofdisplacement dummies and a survey-date dummy variable. The results reported in Table 3 are not appreciably affected by this change in the specification. 
Table 3: Coefficients on Layoff Dummy in Earnings Equations

January 1984 and 1986 CPS Displaced Workers Surveys

Males Re-employed At Survey Date

Dependent Variable - (1) Log(Current wage/Previous wage),

(2) $\log$ (Previous wage), (3) Log(Current wage)

\begin{tabular}{|c|c|c|c|c|}
\hline Sample & $\mathbf{N}$ & $\begin{array}{c}\text { Wage } \\
\text { Change } \\
(1)\end{array}$ & $\begin{array}{l}\text { Pre- } \\
\text { Displ. } \\
\text { (2) }\end{array}$ & $\begin{array}{l}\text { Post- } \\
\text { Displ. } \\
(3)\end{array}$ \\
\hline Whole Sample & 3427 & $\begin{array}{l}-.040 \\
(.017)\end{array}$ & $\begin{array}{c}.017 \\
(.014)\end{array}$ & $\begin{array}{l}-.021 \\
(.017)\end{array}$ \\
\hline White Collar & 1179 & $\begin{array}{l}-.055 \\
(.028)\end{array}$ & $\begin{array}{r}-.0094 \\
(.024)\end{array}$ & $\begin{array}{l}-.064 \\
(.029)\end{array}$ \\
\hline Blue Collar & 2248 & $\begin{array}{l}-.024 \\
(.022)\end{array}$ & $\begin{array}{l}.022 \\
(.017)\end{array}$ & $\begin{array}{l}.0023 \\
(.021)\end{array}$ \\
\hline Low Union & 1716 & $\begin{array}{l}-.040 \\
(.023)\end{array}$ & $\begin{array}{l}-.007 \\
(.020)\end{array}$ & $\begin{array}{l}-.046 \\
(.024)\end{array}$ \\
\hline High Union & 1711 & $\begin{array}{l}-.031 \\
(.026)\end{array}$ & $\begin{array}{l}.030 \\
(.020)\end{array}$ & $\begin{array}{l}.002 \\
(.004)\end{array}$ \\
\hline
\end{tabular}

The reported regressions include a spline function in previous tenure (with breaks at one, two, three, and six years), education, a dumny for advance notification of displacement, year-of-displacement dummies, 7 previousindustry dummies, 8 previous-occupation dummies, experience (age - education - 6) and its square, a marriage dummy, a nonwhite dummy, and 3 region dummies. Columns (1) and (3) also include years since displacement. The white-collar sample consists of workers with pre-displacement jobs as managers and administrators, professional and technical workers, clerical workers, or sales workers. The blue-collar sample consists of workers with pre-displacement jobs as craft and kindred workers, operatives, laborers, transport operatives, or service workers. The low-union sample consists of workers in industry-occupation cells with unionization rates of less than 25.5 percent in 1983; all workers in industry-occupation cells with higher unionization rates are in the high-union sample. Earnings are deflated by the GNP deflator. The numbers in parentheses are standard errors. 
displacement characteristics who were displaced in plant closings. This effect is perhaps stronger than it might appear because it is net of two competing effects: first, as mentioned in the Introduction, workers involved in plant closings seem more likely to be located in distressed local labor markets; and second, many of the layoffs in the sample are likely to have been determined by strict seniority systems. On the other hand, columns (2) and (3) reveal that the estimate in column (1) arises both from the slightly higher pre-displacement earnings and from the slightly lower post-displacement earnings of those displaced by layoffs. Our model predicts only the lower post-displacement earnings; the higher pre-displacement earnings are consistent with the existence of wage concessions before a plant closing, as well as with a compensating difference for layoff (but not plant-closing!) risk.

Separate estimates of the effect of cause of displacement on the wage changes of white- and blue-collar workers are also presented in Table 3. Among white-collar workers, re-employment earnings are estimated to be more than 6 percent lower for those displaced by layoffs than for those displaced by plant closings; no similar difference is apparent for bluecollar workers. Thus, for white-collar workers there is fairly strong evidence supporting the lemons effect (in the re-employment wage equation) and no evidence supporting the wage-concession or compensating-difference effects (in the pre-displacement wage equation).

An alternative approach to determining whether workers were displaced from jobs that were likely to be governed by formal layoff-by-seniority rules is to classify workers by the likelihood that their pre-displacement jobs were unionized. Since the DWS does not provide information on whether 
a worker's pre-displacement job was unionized, we used the extent of unionization in a worker's pre-displacement industry-occupation cell to determine whether the worker's pre-displacement job was likely to be covered by a collective-bargaining agreement. We used all twelve outgoing rotation groups from the 1983 Current Population Survey (the Full Year sample) to generate a sample of workers comparable to our DWS sample and then to compute unionization rates for white- and blue-collar workers in each three-digit industry (as defined in the 1980 Census of Population). 18 We then classified workers into high- and low-union sub-samples depending on whether their pre-displacement industry-occupation cell had a unionization rate above or below the sample median rate of 25.5 percent. The mean unionization rates in the high- and low-union sub-samples are 50.3 and 9.7 percent, respectively.

Estimates of the effect of cause of displacement on the earnings of workers by unionization class are presented in the last two rows of Table 3. The layoff coefficients for the low-union sample are qualitatively similar to but not as large as the analogous coefficients for the whitesample. In particular, the re-employment earnings of low-union workers displaced by layoffs are estimated to be approximately 4.5 percent lower than are those of low-union workers displaced by plant-closings, while no such gap is apparent in the high-union sample.

In sum, the estimates in Table 3 are consistent with the view that the

${ }^{18}$ Unionization rates were computed for 420 industry-occupation cells using a 210-industry by 2-occupation (i.e., white- and blue-collar) classification scheme. The sample was restricted to 20 to 61 year-old, male, full-time, private-sector employees not working in agriculture or construction. The sample consisted of 53,972 observations satisfying these criteria. Workers were classified as unionized if they were union members and/or employed in a job covered by a collective-bargaining agreement. 
information content of a layoff is greater where employers have more discretion over whom to lay off. As noted in the Introduction, however, the information content of a layoff also is greater where employers have better information about workers' abilities. Since some time may have to elapse before the current employer can accurately evaluate a worker's ability (perhaps because the employer is unable to learn the worker's ability until the worker learns the job), it may be that layoffs after brief employment spells signal little information to prospective employers. To study this possibility, we explored whether the lemons effect associated with layoffs differs for workers with more versus less pre-displacement job tenure. We re-estimated the regressions in rows 1 through 3 of Table 3 after replacing the layoff dumm with two interactions between the layoff dummy and two pre-displacement tenure dummies---a low-tenure dummy for predisplacement tenure less than two years and a high-tenure dummy for predisplacement tenure of at least two years. The results of these regressions are presented in Table $4 .^{19}$

The estimates in Table 4 reveal that the effect of a layoff (versus a plant closing) on a displaced worker's wages varies dramatically with pre. displacement tenure. For the whole sample and for white-and blue-collar workers considered separately, workers with less than two years of tenure experience essentially no (statistically significant) differential effect from a layoff. Not surprisingly, therefore, the estimates for workers with

${ }^{19}$ We also computed the analogous estimates using low- and high-tenure dumies defined as less than and at least one year of pre-displacement tenure, respectively. Because the sample of such low-tenure workers is extremely small, the estimates for the low-tenure sub-sample are quite imprecise and the estimates for the high-tenure sub-sample are very similar to the estimates for the whole sample presented in Table 3 . 
Table 4: Coefficients on Interaction of Layoff Dummy with Low- and HighTenure Dummies in Earnings Equations

\section{January 1984 and 1986 CPS Displaced Workers Surveys Males Re-employed At Survey Date}

Low-Tenure - less than 2 years of tenure on pre-displacement job High-Tenure - at least 2 years of tenure on pre-displacement job

Dependent Variable - (1) Log(Current wage/Previous wage), (2) $\log$ (Previous wage), (3) Log(Current wage)

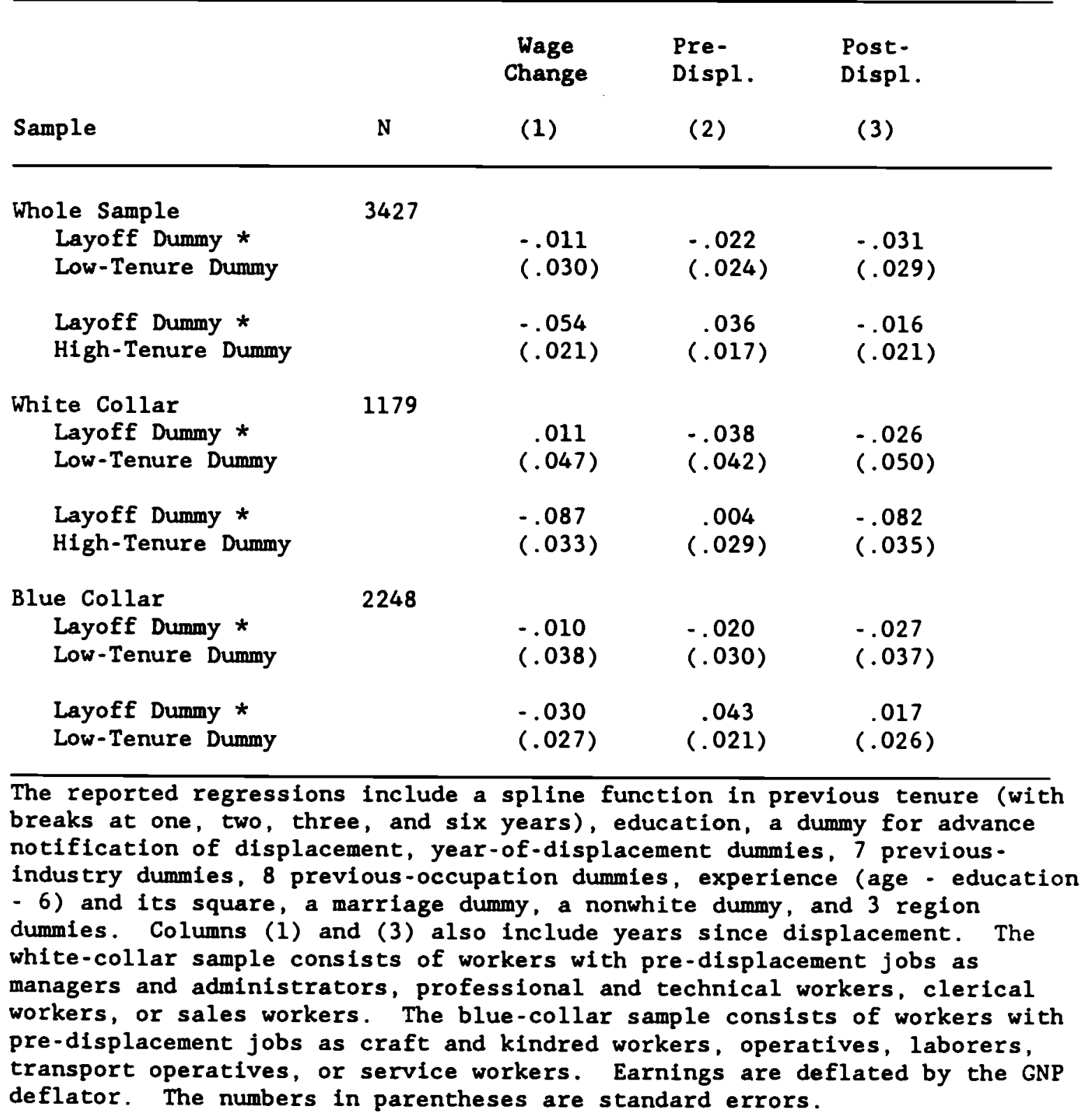


at least two years of tenure are amplified versions of the estimates that do not allow for tenure differences (presented in Table 3). For hightenure white-collar workers, for example, the extra loss in postdisplacement earnings following a layoff rather than a plant closing is 8.2 percent rather than the 6.4 percent for all white-collar workers reported in Table 3: As before, the analogous loss for high-tenure blue-collar workers is zero, as is the influence of a layoff on the pre-displacement earnings of high-tenure white-collar workers. Unlike in Table 3, however, the influence of a layoff on the pre-displacement earnings of high-tenure blue-collar workers is now (a statistically significant) 4 percent rather than (an insignificant) 2 percent.

\section{Sensitivity Analyses}

Since the equations presented in Table 3 were estimated on the sample of displaced workers who were re-employed at the survey date, the estimates may potentially reflect sample-selection bias. We have taken two approaches to probe the importance of this problem. First, we re-estimated the models presented in Table 3 using the two-stage sample-selection bias correction approach of Heckman (1979). ${ }^{20}$ The Heckit estimates of the layoff-dummy coefficient are similar to the ols estimates presented in

20 The re-employment probit equations in the first stage of the Heckit procedure were estimated on our basic sample plus displaced males who were unemployed, self-employed, or employed and earning less than $\$ 40$ dollars a week at the survey date. The re-employment probits included the same variables as the independent variables in the wage regressions in Table 3 . Since we could not make a convincing exclusion restriction (i.e., identify a variable that affects the probability of re-employment at the survey date but does not affect earnings), the Heckit models are identified only by the nonlinearity of the sample-selection bias correction term (the inverse Mills ratio). 
Table 3 in all cases. For example, the Heckit estimates of the layoffdummy coefficients for white-collar workers are -0.55 in the wage change equation, -0.0093 in the pre-displacement earnings equation, and -0.064 in the post-displacement earnings equation. 21

As a second approach to the sample-selection problem, we examined the sub-sample of workers who were displaced at least two years prior to the survey date. These workers have had a substantial amount of time to find a new job. Also, the effects of short-lived bad matches and temporary jobs after displacement should be reduced. Estimates of the layoff coefficient for this sub-sample of displaced workers are presented in Table 5. The layoff effects for white-collar workers displaced at least two years before the survey date are similar to the analogous effects for the entire whitecollar sample, and the findings for the whole sample and for blue-collar workers are in the spirit of the analogous results in Table 3.

In addition to sample-selection bias, a second potential bias arises because the DWS asks respondents about events that occurred as long as five years prior to the survey date. Thus, some respondents may have either completely forgotten events that occurred in the distant past or remembered such events but misreported the dates at which they occurred, or both. Robert Topel has alerted us to one possible manifestation of this kind of retrospection bias: a comparison of the layoffs reported in the 1984 and 1986 DWS's for the years these surveys have in common (1981-3) reveals that

21 The Heckit estimates provide no evidence of statistically significant selection bias in the pre-and post-displacement earnings equations for white-collar workers nor in any of the equations for bluecollar workers. The selection bias correction term enters moderately significantly in the wage-change equation for white-collar workers (a coefficient of 0.055 with a standard error of 0.31 ), although its inclusion does not effect the estimate of the layoff-dummy coefficient. 
Table 5: Coefficients on Layoff Dummy in Earnings Equations

January 1984 and 1986 CPS Displaced Workers Surveys

Males Displaced at Least 2 Years before the Survey Date and Re-employed at the Survey Date

Dependent Variable = (1) Log(Current wage/Previous wage),

(2) Log(Previous wage), (3) Log(Current wage)

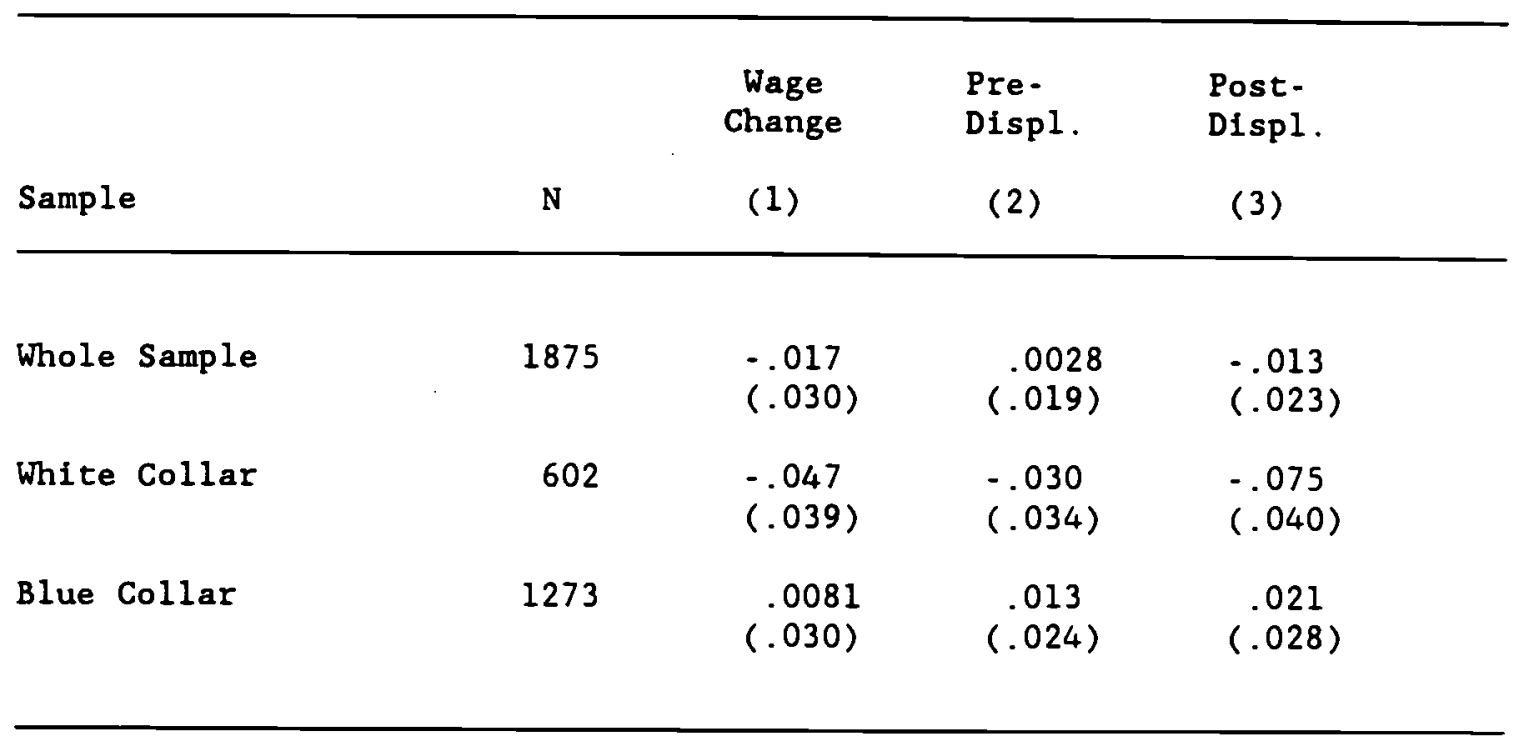

The reported regressions include a spline function in previous tenure (with breaks at one, two, three, and six years), education, a dummy for advance notification of displacement, year-of-displacement dummies, 7 previousindustry dummies, 8 previous-occupation dummies, experience (age - education - 6) and its square, a marriage dummy, a nonwhite dummy, and 3 region dummies. Columns (1) and (3) also include years since displacement. The white-collar sample consists of workers with pre-displacement jobs as managers and administrators, professional and technical workers, clerical workers, or sales workers. The blue-collar sample consists of workers with pre-displacement jobs as craft and kindred workers, operatives, laborers, transport operatives, or service workers. Earnings are deflated by the GNP deflator. The numbers in parentheses are standard errors. 
many more layoffs are reported in the 1984 survey than in the 1986 survey, while the analogous comparison of the plant closings reported at the two survey dates reveals a much smaller difference. ${ }^{22}$ One might hypothesize that (i) this large difference between the layoffs reported in 1984 versus those reported in 1986 results because some 1986 respondents have simply forgotten layoffs that occurred between 1981 and 1983, and (ii) these forgotten layoffs were disproportionately those that did not result in large earnings losses. (Implicit in this pair of hypotheses is the notion that plant closings are memorable, even if they do not result in large earnings losses.)

In Appendix 2, we describe a detailed investigation of the possibility that such retrospection bias is an important factor behind our empirical results. In brief, we find three reasons why retrospection bias appears not to be a problem here: First, while we cannot reject the possibility that such a bias explains our results for the sample as a whole, the data do not support the conjecture that such a bias explains our results for white-versus blue-collar workers. Second, the presence of such a bias would seem to suggest that the lemons effect should grow (in absolute value) with years since displacement, but it does not. And third, the effect of such a bias would seem to be reduced for workers displaced from jobs with long pre-displacement tenure, but (as reported in Table 4) the qualitative properties of our empirical results are not only preserved but

${ }^{22}$ In our sample (including those not re-employed at the survey date), the layoffs reported in the 1984 DWS are 314, 504, and 484 for 1981-3, respectively, while those reported in the 1986 DWS are 142, 258, and 188 for the same years. The plant closings reported in the 1984 DWS, in contrast, are 238, 298, and 272 for 1981-3, respectively, while those reported in the 1986 DWS are 227, 247, and 242 for the same years. 
even strengthened by focusing on workers with long pre-displacement tenure.

\section{Unemployment and Reason for Displacement}

Like wage changes at displacement, the unemployment experiences of displaced workers also appear to differ substantially by the reason for displacement. In Table 1 we found that among permanently displaced workers who were reemployed at the survey date those displaced by plant closings were less likely to have experienced a spell of unemployment after displacement and had fewer weeks of joblessness following displacement than did workers displaced by layoffs. ${ }^{23}$

Two explanations are available for the shorter unemployment spells experienced by workers permanently displaced by plant closings relative to those experienced by workers permanently displaced by layoffs. The first explanation, due to Katz (1986), focuses on the importance of recall expectations in the job-search behavior of the unemployed: workers displaced by layoffs are more likely to think they may be recalled to their pre-unemployment jobs than are workers displaced in plant closings; higher recall expectations are likely to reduce the new-job-finding rate by reducing search intensity and making workers choosier about new jobs. Katz and Meyer (1988) find evidence in support of this view: in a sample of unemployment insurance (UI) recipients in Missouri, workers who expected to

23 (1988) using the 1984 DWS. Similarly, Katz (1986) finds using a sample of household heads from the Panel Study of Income Dynamics that workers who enter unemployment through layoffs have lower escape rates from unemployment through the finding of new jobs than do those displaced through plant closings. 
be recalled at the time of job loss have much lower (approximately 50 percent lower) new-job-finding rates than do workers who did not expect to be recalled.

The second explanation for the shorter unemployment spells experienced by workers displaced by plant closings relative to those experienced by workers permanently displaced by layoffs involves a simple extension of our lemons model. The model developed in Section 2 yields predictions about wage changes at displacement, but also predicts that there will be no postdisplacement unemployment. The latter prediction arises for a simple reason: for any belief about a worker's ability, there is always a wage low enough that firms will be willing to hire the worker.

To generate post-displacement unemployment, the model could be changed so that for sufficiently pessimistic beliefs about a worker's ability either no firm is willing to hire the worker or it takes time for the worker to find a firm that is willing to hire him or her. One could imagine, for example, that some firms use technologies that are extremely sensitive to the worker's ability, so that hiring a bad worker is (essentially) infinitely costly, while other firms use technologies like that described in Section 2, so that there always exists a wage low enough to make the latter firms willing to hire a bad worker. Adding such technological heterogeneity and a job-search mechanism to our lemons model would yield positive (but finite) post-displacement unemployment durations. The expected duration would be longer for workers displaced by layoffs (again, because of the lemons effect) than for workers displaced by plant closings.

In an attempt to assess the extent to which a lemons effect 
contributes to the longer unemployment spells experienced by workers permanently displaced by layoffs relative to the spells experienced by workers displaced in plant closings, we used the January 1986 DWS to construct a sample of first spells of joblessness for 20 to 61 year-old males permanently displaced from full-time, private-sector jobs not in agriculture or construction. ${ }^{24}$ The sample contains 830 complete initial spells of joblessness and 498 censored spells.

We analyze the duration of initial spells of joblessness for this sample using formal hazard-model techniques. We parameterize the hazard rate (i.e., the escape rate from joblessness) using a Weibull specification. The hazard rate for individual $i$ at time $t$ is specified as

$$
\lambda_{1}(t)=\alpha t^{\alpha-1} \exp \left(X_{1} \delta\right)
$$

where $x_{i}$ is a vector of time-invariant covariates for individual $i, \alpha$ is the Weibull duration-dependence parameter, and $\delta$ is a vector of parameters. $^{25}$ Let $T_{i}$ be the length of individual i's unemployment spell. The Weibull specification of the hazard function implies that the $\log$ of

$$
24
$$
jo January 1984 DWS only provides information on total weeks of joblessness since displacement and so does not allow one to determine the length of the initial spell of joblessness. The January 1986 DWS, in contrast, provides information on the number of jobs held by a worker since displacement. This variable and information on total weeks of joblessness since displacement allow one to determine both the length of the initial spell of joblessness for those employed in their first job since displacement at the survey date and the censored length of the initial spell for those who had not worked since displacement. The variable that measures weeks of joblessness since displacement is top-coded at 99 . We treat initial spells of joblessness top-coded at 99 as being censored at 99 weeks.

${ }^{25}$ See Kalbfleisch and Prentice (1980, pp. $23-25$ and $30-32$ ) for a discussion of the properties of the Weibull model. 
the failure time for $i\left(i, e ., Y_{i}-\log _{i}\right.$ ) can be written as a regression model of the form

$$
\mathrm{Y}_{\mathrm{i}}-\mathrm{X}_{\mathrm{i}} \beta+\sigma \varepsilon_{\mathrm{i}}
$$

where $\sigma-1 / \alpha$ is known as the Weibull scale parameter, $\beta=-\sigma \delta$, and $\varepsilon_{i}$ is an error term with an extreme-value distribution (Kalbfleisch and Prentice, 1980, pp. 22-24).

Table 6 presents maximum-likelihood estimates of Weibull duration models for the initial spell of joblessness following displacement for our 1986 DWS sample. ${ }^{26}$ For ease of interpretation, we present the estimates in the form of the regression model in equation (9): we report the parameter $\beta_{j}$ for each covariate $\mathrm{X}_{\mathrm{j}}$. The estimates presented in Table 6 thus can be interpreted as the effects of the covariates on the expected log duration of joblessness.

The coefficient estimate for the layoff dummy in column (1) of Table 6 indicates that workers permanently displaced by layoffs have approximately 25 percent longer initial unemployment spells than do those displaced in plant closings. This finding is consistent with our (extended) lemons model, but of course also is consistent with a recall-expectations model. In columns (2) through (4) of Table 6 we attempt to isolate the effect due

${ }^{26}$ One cannot directly compare the estimates in Table 6 with those by Katz (1986) and Katz and Meyer (1988), because the samples and estimation strategies differ in important ways. The Katz and Katz-Meyer data sets include recalled workers, so those studies estimate models that treat recall as a competing risk (i.e., as a second way that the unemployment spell can end). Because the DWS does not include recalled workers, our estimates of the effects of proxies for recall expectations on unemployment duration are likely to be biased towards zero. 
Table 6: Effects of Selected Variables on the Duration of the First Spell of Joblessness Following Displacement

January 1986 CPS Displaced Workers Survey

Males with only one spell of Joblessness Since Displacement at the Survey Date

Dependent Variable - Log(Weeks of Joblessness)

Weibull Duration Model Specification

Variable

(1)
(2)
(3)

(4)

\begin{tabular}{|c|c|c|c|c|}
\hline Layoff $=1$ & $\begin{array}{l}.248 \\
(.086)\end{array}$ & $\begin{array}{l}.244 \\
(.108)\end{array}$ & $\begin{array}{l}.352 \\
(.106)\end{array}$ & $\begin{array}{l}.323 \\
(.126)\end{array}$ \\
\hline Layoff * White Collar & -- & $\begin{array}{l}-.049 \\
(.168)\end{array}$ & $\cdots$ & $\cdots$ \\
\hline Layoff * High Union & $\cdots$ & $\cdots$ & $\begin{array}{l}-.299 \\
(.147)\end{array}$ & - \\
\hline Layoff * Fraction Union & $\cdots$ & $\cdots$ & $\cdots$ & $\begin{array}{l}-.358 \\
(.345)\end{array}$ \\
\hline Fraction Union & - & $\begin{array}{l}1.173 \\
(.266)\end{array}$ & $\begin{array}{l}1.363 \\
(.294)\end{array}$ & $\begin{array}{l}1.326 \\
(.033)\end{array}$ \\
\hline $\begin{array}{l}\text { Previous Tenure in } \\
\text { years }\end{array}$ & $\begin{array}{l}.037 \\
(.007)\end{array}$ & $\begin{array}{l}.034 \\
(.007)\end{array}$ & $\begin{array}{l}.034 \\
(.007)\end{array}$ & $\begin{array}{l}.033 \\
(.007)\end{array}$ \\
\hline $\begin{array}{l}\text { Log of Previous } \\
\text { Real Weekly Earnings }\end{array}$ & $\begin{array}{l}-.301 \\
(.100)\end{array}$ & $\begin{array}{l}-.339 \\
(.099)\end{array}$ & $\begin{array}{l}-.331 \\
(.099)\end{array}$ & $\begin{array}{l}-.333 \\
(.099)\end{array}$ \\
\hline $\begin{array}{l}\text { Weibull Scale } \\
\text { Parameter }(\sigma)\end{array}$ & $\begin{array}{l}1.146 \\
(.033)\end{array}$ & $\begin{array}{l}1.139 \\
(.032)\end{array}$ & $\begin{array}{l}1.137 \\
(.032)\end{array}$ & $\begin{array}{l}1.139 \\
(.032)\end{array}$ \\
\hline Log Likelihood & -1831.3 & -1822.2 & -1820.2 & -1821.7 \\
\hline
\end{tabular}

The reported models were estimated by maximum likelihood with left censoring explicitly treated using the LIFEREg procedure in SAS. The sample size is 1228. The reported specifications include education, a dummy for advance notification of displacement, year-of-displacement dummies, 7 previousindustry dummies, 8 previous-occupation dummies, experience (age - education - 6) and its square, a marriage dummy, a nonwhite dummy, and 3 region dummies. Fraction union is the 1983 fraction unionized of the worker's predisplacement industry-occupation cell. High union equals one for workers displaced from industry-occupation cells where the fraction unionized was greater than 0.255 in 1983 ; it equals 0 otherwise. Earnings are deflated by the GNP deflator. The numbers in parentheses are asymptotic standard errors. 
solely to the lemons model.

The estimates in column (2) indicate that the effect observed in column (1) for the whole sample also appears in both the white- and bluecollar sub-samples of our data set: workers permanently displaced by layoffs experience significantly longer initial unemployment spells than do workers displaced by plant closings, regardless of whether the displacement is from a white- or blue-collar job. (More precisely, the point estimates in column (2) suggest that the effect is slightly smaller for white-collar workers, but not statistically significantly so.) Since white-collar workers are much less likely to expect to be recalled than are blue-collar workers, ${ }^{27}$ the similarity in the impact of the layoff dummy on unemployment durations for the two groups suggests that a lemons effect may be influencing the post-displacement unemployment duration of white-collar workers permanently displaced by layoffs. The lemons effect appears to be compensating for the reduced importance of the layoff dummy for whitecollar workers that would be predicted by the recall-expectations model alone.

The estimates in columns (3) and (4) are analogous to those in column (2), except that we use a second approach to attempt to define a sub-sample of jobs that are likely to be governed by formal layoff-by-seniority rules,

${ }^{27}$ Evidence on differences in the importance of recall expectations for white-collar and blue-collar displaced workers is available from a sample of UI recipients from Missouri and Pennsylvania in 1979-80. This sample, which is described in detail in Katz and Meyer (1988), contains direct information on whether workers expected to be recalled when they filed for UI benefits. For this sample, we find that 58 percent of blue-collar workers who had spells that ended in a new job initially expected to be recalled by their previous employer, while only 25 percent of the comparable sample of white-collar workers expected to be recalled. This suggests that the recall-expectations model should be substantially less important for white-collar workers. 
and therefore not likely to be subject to a lemons effect. As in Section $3 B$, we classify each worker in terms of a measure of the extent of unionization in the worker's pre-displacement industry and occupation (as described in footnote 17).

In column (3) our measure of the extent of unionization is a dummy variable equal to one if the unionization rate exceeds 25.5 percent (the median of the sample described in Section 3B). We find that for workers from low-unionization pre-displacement industries and occupations, those displaced by layoffs experience significantly longer (approximately 35 percent longer) post-displacement unemployment durations than do those displaced by plant closings. We also find that the effect of displacement by layoff on unemployment duration is statistically significantly different for low- versus for high-unionization workers: for workers from highunionization pre-displacement industries and occupations, those displaced by layoffs experience only 5 percent longer unemployment spells than do those displaced by plant closings. In column (4) we interact the layoff dummy with the unionization rate (i.e., the continuous variable that underlies the unionization dummy described above) of the worker's predisplacement industry and occupation. The results for are qualitatively similar to those reported in column (3).

Because workers from high-unionization pre-displacement industries and occupations are much more likely to be covered by layoff-by-seniority rules, the lemons effect ought to be much weaker for this sub-sample. The findings reported in columns (3) and (4) are consistent with this view. Interestingly, it is somewhat more difficult to reconcile these findings with the recall-expectations model. Because of the well known importance 
of the layoff-recall process in the unionized sector of the United States labor market, one might expect that workers laid off from high-unionization pre-displacement industries and occupations would experience much longer unemployment durations than would high-unionization workers displaced by plant closings, rather than only 5 percent longer as we estimate in column (3). It could be, however, that layoffs of high-unionization workers during this period occurred primarily in declining industries, so that recall expectations were low.

In sum, the evidence presented in Table 6 shows that workers permanently displaced by layoffs experience significantly longer initial unemployment durations following displacement than do workers displaced by plant closings. While both our (extended) lemons model and a recallexpectations model are capable of explaining this fact, we find that the result persists for sub-samples that seem likely to fit the lemons model but unlikely to fit the recall-expectations model.

\section{Summary and Interpretation}

In this paper, we develop and find modest empirical support for an asymmetric-information model of layoffs. The model is based on a seemingly plausible form of asymmetric information: a worker's current employer is assumed to be better informed about the worker's productive ability than prospective employers are. The key feature of the model is that when firms have discretion with respect to whom to lay off, the market will infer that laid-off workers are of low ability. Since no such negative inference should be attached to workers displaced in a plant closing, our model 
predicts that the post-displacement wages of otherwise observationally equivalent workers will be higher for those displaced by plant closings than for those displaced by layoffs. A simple extension of our model predicts that the average post-displacement unemployment spell of otherwise observationally equivalent workers will be shorter for those displaced by plant closings than for those permanently displaced by layoffs.

Using data on a large sample of permanently displaced workers, we find two kinds of evidence consistent with the lemons effect predicted by our model. First, the post-displacement earnings of white-collar workers who are displaced by layoffs are significantly lower than those of white-collar workers displaced by plant closings. Second, white-collar workers permanently displaced by layoffs endure post-displacement unemployment spells that are significantly longer than those endured by white-collar workers displaced by plant closings. The fact that this evidence is consistent with our model may bode well for future theoretical and empirical work on wages and mobility based on the information asymmetry we analyze. Alternatively, our empirical results can be interpreted as support for various plausible symetric-information models, as follows.

To be concrete, suppose that at the beginning of a worker's career, information about the worker's productive ability is imperfect but symmetric: the worker, the firm, and the market all hold the same (imprecise) belief. ${ }^{28}$ Suppose further that as the worker's career

${ }^{28}$ Such an information structure would arise if, for example, the worker's schooling is a noisy indicator of the worker's productive ability and, unlike the familiar Spence formulation, the combination of the worker's lack of experience in the labor market and firms' wealth of experience in evaluating new workers implies that the worker and all the firms are equally able to predict the worker's productive ability. 
progresses, the worker, the firm, and the market all observe the same information about the worker's performance. Then at any point in the worker's career, the worker, the firm, and the market all will hold a common belief about the worker's ability.

In order for such a symmetric-information model to yield the desired predictions about the effect of cause of displacement on re-employment wages and unemployment durations, the model must include a description of why layoffs occur. One reason layoffs might occur is that wages are sticky (perhaps because wages are attached to jobs, as in an internal labor market), so that the firm cannot reduce the worker's wage even if the worker's productivity turns out to be much lower than was at first expected. In this case, if the firm suffers an adverse productivity or demand shock, it may prefer to lay off the worker rather than to retain the worker at the original wage. Because information is symmetric, the market does not learn from the layoff per se (unlike in our lemons model), but the market does take the opportunity that a layoff presents to reduce the worker's wage.

A second reason layoffs might occur in a symmetric-information model involves sorting. Suppose, for instance, that there are two industries: in industry $A$, output is very sensitive to ability, while in industry $B$, output is relatively insensitive to ability. Thus, if information about workers' productive abilities were perfect, then high-ability workers would be employed in industry $A$ and low-ability workers would be employed in industry B. As described above, however, information about workers' abilities is imperfect but improves over time. As a result, at the beginning of their careers, workers who appear to be of high- 
(respectively, low-) ability are employed in industry A (respectively, B). Over time, as new information about workers' productive abilities becomes available, mobility endogenously improves the sorting of workers into industries. $^{29}$ Two kinds of mobility occur: workers who perform surprisingly well move from industry $B$ to $A$, while those who perform surprisingly poorly move from industry A to $B$. If we call the former a quit and the latter a layoff, then this sorting model also generates the main empirical prediction of our lemons model: laid-off workers receive low re-employment wages.

Unlike these sticky-wage and sorting models, many other symmetricinformation models do not provide convincing explanations for why layoffs occur. In models in which a worker of a given ability is equally productive in all firms, for instance, the equilibrium response to bad news about a worker's ability is a wage reduction, not a layoff. Similarly, in matching models in which match quality with one firm provides no information about match quality with any other firm (as in Jovanovic, 1979), bad news about match quality at the current firm motivates a separation that looks more like a quit than a layoff, and can even result in a wage increase rather than a wage reduction. Our asymmetricinformation model, in contrast, strongly motivates a layoff rather than a wage reduction in response to bad news about a worker's ability: in

${ }^{29}$ See Gibbons and Katz (1987) for a precise statement of this model, which is a dynamic version of Roy's (1951) model, extended to include imperfect information, learning, and endogenous mobility. The model is closely related to the models of wages and turnover developed by Jovanovic (1979) and MacDonald (1982) except that: (i) in this model (as opposed to Jovanovic's) a worker's performance in one industry determines not only the expected value of staying in that industry but also the expected value of moving to the other industry; and (ii) in this model (as opposed to MacDonald's) ability measures absolute rather than comparative advantage. 
equilibrium, the firm cannot retain low-ability workers at a low wage: if it could, it would also retain high-ability workers at the low wage, which would destroy the market's willingness to allow any workers to be retained at the low wage.

In sum, the predictions of our lemons model also can be generated by some (but not all!) symmetric-information models. Our empirical results therefore are not conclusive proof that asymmetric information plays an important role in the labor market. Rather, we interpret the results as a necessary (but not sufficient) condition for confidence in models based on asymmetric information about workers' abilities:' had our estimates rejected our model, it would have cast serious doubt on the entire family of models based on this kind of asymmetric information (as well as on the symmetricinformation models that generate the same predictions). Unfortunately, the nature of asymmetric information seems to imply that direct empirical tests of its importance are not possible, so indirect tests of the kind presented here may be all that is possible. 


\section{APPENDIX 1: Productivity Shocks}

In the model in the text, layoffs occur even though they waste firmspecific human capital. This inefficiency is a consequence of the assumption that employers cannot commit to a particular kind of long-term contract: we assume that it is impossible to enforce a contract signed at the beginning of period one that specifies that no workers will be laid off at the beginning of period two. In this Appendix we introduce a reason why the firm may be unable to commit to such a long-term contract: at the beginning of period two there is a firm-specific productivity shock that could be severe enough to bankrupt the firm if it were forced to retain all its first-period employees.

To model such a shock, let the second-period output of a worker of ability $\eta$ be $y_{2}(\eta)-(1+s) \eta+\theta$ if the worker remains with the firstperiod employer, but $y_{2}(\eta)-\eta$ if the worker changes employers. Thus, $\theta$ represents a firm-specific productivity (or demand) shock: the worker's productivity with prospective employers is unaffected by $\theta$. Furthermore, in this (sketch of a) model the prospective employers do not experience firm-specific shocks of their own. ${ }^{30}$

Assume that $\theta$ is observed by the current employer and by prospective employers at the beginning of period two, before the current employer decides whether to lay off or retain a particular worker. Then all of the

${ }^{30}$ In a complete model, each employer would experience an independent second-period productivity shock, drawn (say) from a single distribution $g(\theta)$. Given the constant returns to scale assumed above, the bidding by prospective employers for laid-off workers would be won by the employer with the highest realization of $\theta$. A more natural model would allow for decreasing returns to scale. We expect, however, that in all such models the qualitative results derived in this sub-section would continue to hold. 
analysis summarized in equations (1) - (4) above carries over, except that the equilibrium cutoff now depends on $\theta$ : the current employer retains workers of ability $\eta \geq \eta^{*}(\theta)$. As before, ( 7 ) holds, so $w_{2}(P C)-w_{2}(L)>0$, where $w_{2}(L)-E(\eta \mid \eta<\eta *(\theta))$, analogously to (2). Furthermore, we have

Proposition 2: In the unique pure-strategy equilibrium, $\eta *(\theta)$ is given by:

(1) for $\theta<-s \eta, \eta *(\theta)-0$; (ii) for $-s \eta \leq \theta \leq E(\eta), \eta *(\theta)$ solves

$$
\eta *(\theta)(1+s)+\theta-E(\eta \mid \eta \geq \eta *(\theta))
$$

and (iii) for $\theta>E(\eta), \eta^{*}(\theta)=\eta$. For $-s \eta<\theta<E(\eta), \eta *(\theta)$ decreases with $\theta$, so $w_{2}(P C)-w_{2}(L)$ increases with $\theta$.

Proof: Parts (i) and (iii) are straightforward. Uniqueness in (ii) follows as in the text. Monotonicity in (ii) follows by totally differentiating (A.1), which yields $(1+s) \eta^{*^{\prime}}+1=\eta^{*^{\prime}} d\left(E\left(\eta \mid \eta \geq \eta *^{*}\right)\right) / d \eta *$, where $\eta^{*}-\mathrm{d} \eta *^{\prime} / \mathrm{d} \theta$. By $\log$-concavity, $d\left(E\left(\eta \mid \eta \geq \eta^{*}\right)\right) / \mathrm{d} \eta^{*} \leq 1$, so $\eta^{*}<0$. Q.E.D.

The intuition for the result that $\eta^{\star}(\theta)$ decreases in $\theta$ is simple: in bad times, employers lay off many workers, and the associated inference about these workers' abilities is not as severe. In the extreme case, the shock is large enough to generate a plant closing, and no adverse inference is made about the abilities of the displaced workers. 


\section{APPENDIX 2: Retrospection Bias}

In this Appendix we describe a detailed investigation into the retrospection bias summarized in hypotheses ( $i$ ) and ( $i i)$ in the text. Such bias could be responsible for our finding for the sample as a whole (in row 1 of Table 3) that layoffs lead to lower post-displacement earnings than do plant closings. As described in the text, however, we also find (in rows 2 and 3 of Table 3) that the lemons effect following a layoff is much more pronounced for white-collar workers and much less pronounced for bluecollar workers. We find it difficult to modify hypotheses (i) and (ii) so as to account for this latter finding in a plausible way. Furthermore, the evidence suggests that the retrospection bias is less severe for whitethan for blue-collar workers. ${ }^{31}$

In addition to noting that our results for white-versus blue-collar workers do not appear to be driven by retrospection bias, we also attempted to assess the severity of the retrospection bias in two other ways. First, we re-estimated the regressions reported in rows 1 through 3 of Table 3 after replacing the layoff dummy with five interactions between the layoff dummy and the five years-since-displacement dummies. ${ }^{32}$ In the spirit of

${ }^{31}$ In our sample of white-collar workers (including those not reemployed at the survey date), the layoffs reported in the 1984 DWS are 73 , 140 , and 159 for 1981-3, respectively, while those reported in the 1986 DWS are 43,81 , and 73 for the same years. For blue-collar workers, the layoffs reported in 1984 are 241,364 , and 325 for $1981-3$, as compared to and 99, 177, and 115 reported in 1986. If there is a difference between white- and blue-collar workers, therefore, it would seem to be that whitecollar workers forget fewer layoffs. (Note that this qualitative comparison holds even if one focuses on 1981 alone, and so would not seem to be attributable to occupational differences in recall rates.)

${ }^{32}$ Recall that the DWS asks workers about their labor-market experiences during the five years preceding the survey date. 
hypotheses (i) and (ii), one might suppose that layoffs that occurred further in the past are remembered (and reported) only if they resulted in more severe earnings losses, in which case the wage-change and postdisplacement earnings regressions analogous to columns (1) and ( 3 ) of Table 3 should yield coefficients on these five interactions that increase (in absolute value) with years since displacement. We find that nothing like this monotonic pattern of coefficients emerges from the data. Rather, a typical pattern is that the strongest effects are in the first and third years, while the effects in the second, fourth, and fifth years are approximately equal and distinctly smaller than the first-and third-year effects.

In our final attempt to assess the impact of retrospection bias on our results, we re-estimated the regressions in Table 4 after redefining the low-tenure (resp., high-tenure) dumny to refer to workers with less than (resp., at least) three (rather than two) years of pre-displacement job tenure. We did this because, in the spirit of hypotheses (i) and (ii), one might suppose that layoffs from jobs with longer pre-displacement tenure are more likely to be remembered (and reported), ${ }^{33}$ in which case the coefficient on the interaction of the layoff dummy and the high-tenure dummy should suffer less from retrospection bias than does the analogous coefficient on the layoff dummy reported in Table 3 . As noted in the text

${ }^{33}$ In fact, there is some evidence along these lines. For our sample as a whole: (1) the layoffs reported in 1984 by workers with less than three years of pre-displacement job tenure are 164, 247, and 262 for 19813 , respectively, while the layoffs reported in 1986 by such workers are 78 , 126, and 92 for the same years; (2) the layoffs reported in 1984 by workers with at least three years of pre-displacement job tenure are 150, 257, and 222 for 1981-3, respectively, while the layoffs reported in 1986 by such workers are 115, 135, and 113 for the same years. 
in connection with Table 4, however, our findings are only strengthened by focusing on the (two-year) high-tenure sub-sample, and the same is true for this (three-year) high-tenure sub-sample: for white-collar workers with at least three years of tenure on their pre-displacement jobs, for example, the extra loss in post-displacement earnings following a layoff rather than a plant closing is 11 percent, rather than the 6.4 percent for all whitecollar workers reported in Table 3 or the 8.2 percent for white-collar workers with at least two years of pre-displacement tenure reported in Table 4. 


\section{REFERENCES}

Abraham, K. and J. Medoff (1984), "Length of Service and Layoffs in Union and Nonunion Work Groups, " Industrial and Labor Relations Review, 38: 87 97.

Akerlof, G. (1970), "The Market for Lemons: Qualitative Uncertainty and the Market Mechanism," Quarterly Journal of Economics, 84: 488-500.

(1976), "The Economics of Caste and of the Rat Race and Other Woeful Tales," Quarterly Journal of Economics, 90: 599-617.

Caplin, A. and B. Nalebuff (1989), "Aggregation and Social Choice: A MeanVoter Theorem," Princeton mimeo, January.

Gibbons, R. and L. Katz (1987), "Learning, Mobility, and Inter-Industry Wage Differences," NBER mimeo, December.

Greenwald, B. (1986), "Adverse Selection in the Labour Market," Review of Economic Studies, 53: 325-347.

Heckman, J. (1979) "Sample Selection Bias As Specification Error." Econometrica 47: 153-61. and B. Honore (1987), "The Empirical Content of the Roy Model," NORC mimeo, August.

Jovanovic, B. (1979), "Job Matching and the Theory of Turnover," Journal of Political Economy, 87: 972-90.

Kalbfleisch, J. and R. Prentice (1980), The Statistical Analysis of Failure Time Data (New York: Wiley).

Katz, L. (1986), "Layoffs, Recall and the Duration of Unemployment," NBER Working Paper No. 1825, January.

Katz, L. and B. Meyer (1988), "Unemployment Insurance, Recall Expectations, and Unemployment Outcomes," NBER Working Paper No. 2594, May.

Kletzer, L.G. (1988), "Returns to Seniority After Permanent Job Loss," Williams College mimeo, February.

Kruse, D. (1988), "International Trade and the Labor Market Experiences of Displaced Workers," Industrial and Labor Relations Review, 41: 402-417.

Lazear, E. (1986), "Raids and Offer Matching," Research in Labor Economics, 8: Part A, 141-165.

MacDonald, G. (1982), "A Market Equilibrium Theory of Job Assignment and Sequential Accumulation of Information," American Economic Review, 72: $1038-55$. 
Milgrom, P. and S. Oster (1987), "Job Discrimination, Market Forces, and the Invisibility Hypothesis," Quarterly Journal of Economics, 102: 453 476 .

Podgursky, M. and P. Swaim (1987), "Job Displacement and Earnings Loss: Evidence from the Displaced Worker Survey," Industrial and Labor Relations Review, 41: 17-29.

Ricart i Costa, J. (1988), "Managerial Performance and Task Assignment," Econometrica, 56: 449-466.

Riordan, M. and R. Staiger (1987), "Sectoral Shocks and Structural Unemployment," Stanford University, CEPR Publication \#124, December.

Roy, A. (1951), "Some Thoughts on the Distribution of Earnings," Oxford Economic Papers, 3, 135-46.

Topel, R. (1988), "Wages Rise with Job Seniority," University of Chicago mimeo, May.

U.S. Department of Commerce, Bureau of the Census (1986), "January 1986 Displaced Workers and Occupational Training Supplement," CPS Interviewer's Memorandum No. 86-01, section II, Washington, D.C., January.

Waldman, M. (1984), "Job Assignment, Signaling, and Efficiency," Rand Journal of Economics, 15: 255-267. 